\title{
Photocrosslinkable laminin-functionalized polyethylene glycol hydrogel for intervertebral disc regeneration
}

\author{
Aubrey T. Francisco ${ }^{a}$, Priscilla Y. Hwang ${ }^{a}$, Claire G. Jeong ${ }^{a}$, Liufang Jing ${ }^{a}$, Jun Chen ${ }^{b}$, Lori A. Setton ${ }^{\mathrm{a}, \mathrm{b}, *}$ \\ ${ }^{a}$ Department of Biomedical Engineering, Duke University, Durham, NC, USA \\ ${ }^{\mathrm{b}}$ Department of Orthopaedic Surgery, Duke University Medical Center, Durham, NC, USA
}

\section{A R T I C L E I N F O}

\section{Article history:}

Received 17 August 2013

Received in revised form 15 October 2013

Accepted 17 November 2013

Available online $\mathrm{xxxx}$

\section{Keywords:}

Nucleus pulposus

Intervertebral disc

Polyethylene glycol

Photocrosslinking

Laminin

\begin{abstract}
A B S T R A C T
Intervertebral disc (IVD) disorders and age-related degeneration are believed to contribute to lower back pain. There is significant interest in cell-based strategies for regenerating the nucleus pulposus (NP) region of the disc; however, few scaffolds have been evaluated for their ability to promote or maintain an immature NP cell phenotype. Previous studies have shown that NP cell-laminin interactions promote cell adhesion and biosynthesis, which suggests a laminin-functionalized biomaterial may be useful for promoting or maintaining the NP cell phenotype. Here, a photocrosslinkable poly(ethylene glycol)laminin 111 (PEG-LM111) hydrogel was developed. The mechanical properties of PEG-LM111 hydrogel could be tuned within the range of dynamic shear moduli values previously reported for human NP. When primary immature porcine NP cells were seeded onto PEG-LM111 hydrogels of varying stiffnesses, LM111-presenting hydrogels were found to promote cell clustering and increased levels of sGAG production as compared to stiffer LM111-presenting and PEG-only gels. When cells were encapsulated in 3-D gels, hydrogel formulation was found to influence NP cell metabolism and expression of proposed NP phenotypic markers, with higher expression of $\mathrm{N}$-cadherin and cytokeratin 8 observed for cells cultured in softer ( $<1 \mathrm{kPa})$ PEG-LM111 hydrogels. Overall, these findings suggest that soft, LM111-functionalized hydrogels may promote or maintain the expression of specific markers characteristic of an immature NP cell phenotype.
\end{abstract}

(c) 2013 Acta Materialia Inc. Published by Elsevier Ltd. All rights reserved.

\section{Introduction}

Intervertebral disc (IVD) disorders, including herniation, stenosis, spondylolysis, and degeneration, resulted in more than 663,000 inpatients stays for back surgery or other back disorder treatments in the US in 2008 alone, costing more than $\$ 9.5$ billion and making back problems the ninth most expensive condition treated in US hospitals [1]. IVD degeneration is associated with a loss of disc height and hydration, diminished blood supply in the endplates, and anulus fibrosus tears [2-4]. Current therapies for treating disc degeneration include conservative non-surgical approaches and surgical intervention such as discectomy, spinal fusion and total disc replacement; however, these therapies do not restore the structure and function of the native IVD.

Disc degeneration is believed to originate in the nucleus pulposus (NP) region of the disc [3]; therefore, there is significant interest in tissue engineering strategies to regenerate the NP. The native $\mathrm{NP}$ is composed primarily of water, proteoglycans and collagen type II. Age-related degeneration of the NP is characterized by

\footnotetext{
* Corresponding author at: Department of Biomedical Engineering, Duke University, Durham, NC, USA.

E-mail address: lori.setton@duke.edu (L.A. Setton).
}

decreased water content, decreased cellularity, loss of proteoglycans in the extracellular matrix (ECM) and increased matrix stiffness [5,6]. Aging itself is associated with an early loss of the juvenile NP cell population that is originally derived from the embryonic notochord [7-9]. These large, highly vacuolated notochordal-like NP cells organize in cell clusters [7,10,11], synthesize a proteoglycan-rich ECM and secrete soluble mediators that regulate proteoglycan synthesis by other cell types [12-15]. Therefore, the aging-associated loss of this notochordal NP cell population has been hypothesized to be a contributing factor to IVD degeneration, and suggests that promoting or maintaining an immature, notochordal-like NP cell phenotype may be useful for NP tissue regeneration.

It is widely known that ECM protein composition and matrix elasticity play important roles in regulating cellular function. Previous studies have shown region-specific expression of the laminin family of ECM proteins and their receptors in immature IVD tissues [16-18]. Laminins are heterotrimeric ECM proteins that mediate numerous cellular processes such as adhesion, differentiation, migration and survival $[19,20]$. NP cells have been shown to attach to laminins in higher numbers as compared to cells from the adjacent anulus fibrosus, with cell attachment to the laminin-111 (LM111) isoform mediated by the integrin $\alpha 3, \alpha 5, \alpha 6$ and $\beta 1$ 
subunits [16,21,22]. Additional studies have shown that immature primary NP cells cluster and produce more sulfated glycosaminoglycan (sGAG) when cultured on soft, laminin-rich substrates [23]. These findings suggest that a soft, laminin-functionalized biomaterial may maintain or promote the immature NP cell phenotype and biosynthesis.

A variety of synthetic, natural and hybrid materials have been investigated as scaffolds for NP regeneration [24], mainly in the form of hydrogels, which mimic the highly hydrated nature of the native NP. Natural components of the ECM such as hyaluronan [25-27], collagen [28,29] and fibrin [28], and naturally derived polysaccharides such as alginate [28,30,31], chitosan [32-34] and agarose [28], have all been studied as potential scaffolds for NP tissue engineering. One limitation of using natural polymers for tissue engineering is that their mechanical properties cannot be easily controlled. To overcome this, hybrid biomaterials of both natural and synthetic materials [27,34-36], and natural polymers modified to contain functional groups that allow for photocrosslinking $[37,38]$ have been explored as potential scaffolds for NP tissue engineering. Photopolymerizable poly(ethylene glycol) (PEG) hydrogels have been extensively investigated as scaffolds for numerous tissue engineering applications due to their hydrophilicity, biocompatibility and tunable mechanical properties [39]. Since PEG can be easily modified with biofunctional moieties [40,41], ECM-derived peptides and full-length ECM proteins such as collagen $[42,43]$, fibrinogen $[42,44]$ and laminin [45] have been incorporated into PEG hydrogels as a means to control cell-material interactions in three dimensions. We have previously developed a PEG-laminin-111 (PEG-LM111) conjugate capable of supporting NP cell adhesion, which can be crosslinked via the addition of PEG-dithiol and PEG-octoacrylate for use as a biomaterial carrier for cells delivered to the disc [46].

Few studies have attempted to evaluate a scaffold for its ability to maintain or promote the immature or notochordal-like NP cell phenotype [47]. This is likely due to the lack of specific markers that distinguish notochordal-like NP cells from smaller, more chondrocyte-like NP cells, anulus fibrosus cells and articular chondrocytes. A number of recent studies have focused on defining the NP cell phenotype by evaluating biomarker expression in immature or non-degenerate NP cells as compared to that in degenerate NP cells, anulus fibrosus cells or articular chondrocytes [48-51]. Laminin-binding integrin subunits $\alpha 3$, $\alpha 6$ and $\beta 4$ have been shown to be uniquely expressed in cells of the immature NP $[17,52]$. N-Cadherin has been shown to be more highly expressed in NP cells as compared to articular chondrocytes [50] and anulus fibrosus cells [53]. Finally, cytokeratin 8 , an intermediate filament protein, is known to be expressed in notochordal disc cells [54] and more recently has been shown to be differentially expressed in NP cells $[48,50]$. These findings provide useful biomarkers for choosing those scaffold biochemical and physical properties that can promote or maintain an immature NP cell phenotype.

The objective of this work was to develop a laminin-functionalized PEG hydrogel based on well-characterized photocrosslinkable chemistry, and to investigate the effect of laminin ligand presentation and matrix stiffness in maintaining or promoting the immature NP cell phenotype. Here, PEG-LM111 conjugates were crosslinked to form hydrogels upon the addition of PEGdiacrylate and exposure to UV light. We evaluated immature NP cell organization and proteoglycan synthesis when cells were cultured on top of PEG-LM111 hydrogels. Additionally, we describe here the effects of hydrogel stiffness and LM111 concentration on immature NP cell metabolism and NP phenotypic marker expression, including integrin subunits $\alpha 3$ and $\alpha 6$, as well as cytokeratin 8 and N-cadherin, when cells were cultured within 3-D PEG-LM111 hydrogels.

\section{Materials and methods}

\subsection{LM111 PEGylation and PEG-LM111 hydrogel preparation}

PEG-LM111 hydrogels were prepared via a two-step process in which LM111 was PEGylated to introduce functional acrylate groups and crosslinked by photopolymerization with additional PEG-diacrylate (PEG-DA) (Fig. 1). LM111 (Trevigen $^{\circledR}$, Gaithersburg, MD) was PEGylated with acrylate-PEG-N-hydroxysuccinimide (Ac-PEG-NHS, MW $=10 \mathrm{kDa}$, Creative PEGworks, Winston Salem, NC) as described previously [46]. Briefly, Ac-PEG-NHS was added to a LM111 solution at varying molar excess Ac-PEG-NHS (10:1, $25: 1,100: 1$ or $500: 1)$ to synthesize PEG-LM111 conjugates with varying degrees of modification. PEG-LM111 conjugate solution was dialyzed to remove unreacted Ac-PEG-NHS. The LM111 concentration in each PEG-LM111 conjugate precursor solution was determined by measuring the absorbance at $280 \mathrm{~nm}$, and conjugates were stored at $-80^{\circ} \mathrm{C}$ until further use. PEG-DA ( $10 \mathrm{kDa}$, Creative PEGworks) was weighed, sterilized by exposure to UV light $(265 \mathrm{~nm})$ for $30 \mathrm{~min}$, and transferred to sterile Eppendorf tubes. To form PEG-LM111 hydrogels, varying amounts of PEG-LM111 conjugate $\left(0-1000 \mu \mathrm{g} \mathrm{ml}^{-1}\right.$ ) and $10 \mathrm{kDa}$ PEG-DA (2-10\% (w/v), Creative PEGworks) were mixed, injected into custom molds [55] using a 22 gauge needle and $1 \mathrm{ml}$ syringe and polymerized upon exposure to UV light $\left(3-4 \mathrm{~mW} \mathrm{~cm}^{-2}\right)$ in the presence of $0.1 \%(\mathrm{w} /$ v) photoinitiator (Irgacure $2959^{\circledR}$, Ciba Speciality Chemicals, Tarrytown, NY). A number of experiments were performed to evaluate LM111 distribution within PEG-LM111 hydrogels, and cell interactions with PEG-LM111 hydrogels in both two and three dimensions. A summary of PEG-LM111 hydrogel formulations tested and experimental output measures obtained for each formulation is presented in Table 1.

\subsection{LM111 distribution in PEG-LM111 hydrogels}

Immunostaining of PEG-LM111 hydrogels was performed to evaluate the effects of the Ac-PEG-NHS to LM111 ratio used in conjugate synthesis on the amount of protein incorporated into PEG-LM111 hydrogels. PEG-LM111 hydrogels were crosslinked as described above to obtain four different hydrogel formulations containing 5\% (w/v) PEG-DA and $200 \mu \mathrm{g} \mathrm{ml}^{-1}$ PEG-LM111 conjugate synthesized at either $10: 1,25: 1,100: 1$ or $500: 1 \mathrm{M}$ ratio of

PEG-laminin (PEG-LM111) conjugate synthesis

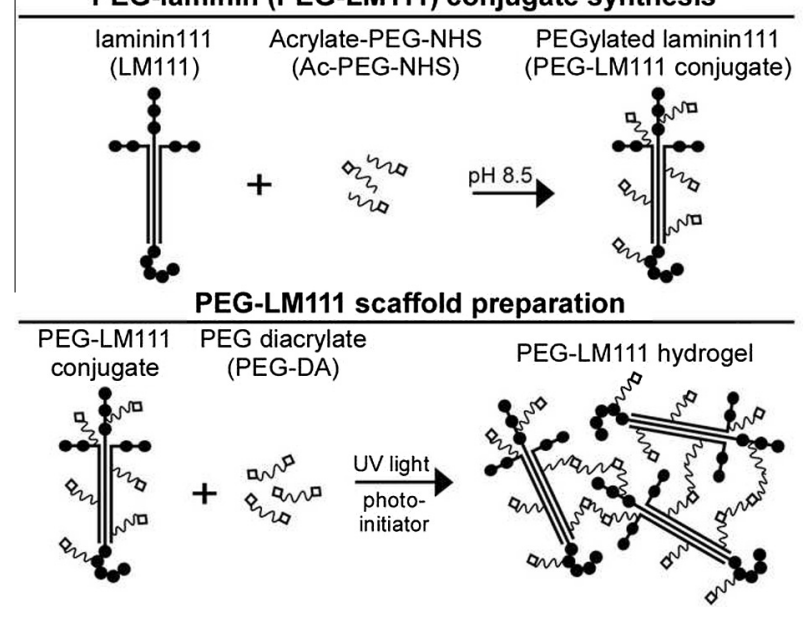

Fig. 1. Schematic of photocrosslinkable PEG-laminin (PEG-LM111) hydrogel preparation. PEG-LM111 conjugates were synthesized by the addition of Ac-PEG-NHS to introduce functional acrylate groups for crosslinking (top). Conjugates were mixed with additional PEG-DA and crosslinked via exposure to UV light to form PEGLM111 hydrogels of varying stiffness and LM111 concentration. 
Table 1

Summary of PEG-LM111 hydrogel formulations and experimental output measures obtained.

\begin{tabular}{|c|c|c|c|}
\hline $\begin{array}{l}\text { PEG concentration(s)\% } \\
(\mathrm{w} / \mathrm{v})\end{array}$ & $\begin{array}{l}\text { LM111 concentration(s) } \\
(\mu \mathrm{g} / \mathrm{ml})\end{array}$ & $\begin{array}{l}\text { Ac-PEG-NHS: LM111 } \\
\text { ratio(s) }\end{array}$ & Output measure(s) \\
\hline 5 & 200 & $0,10,25,100,500$ & LM111 distribution \\
\hline 2,10 & 0,1000 & 25 & 2-D NP cell morphology, sGAG production \\
\hline 6 & 200 & 25 & NP cell viability \\
\hline 5,10 & $0,100,500$ & 25 & Mechanical properties, 3-D media metabolites, NP phenotypic marker expression \\
\hline
\end{tabular}

Ac-PEG-NHS to LM111. Blank 5\% (w/v) PEG-DA hydrogels and 5\% $(\mathrm{w} / \mathrm{v})$ PEG-DA gels mixed with $200 \mu \mathrm{g} \mathrm{ml}^{-1}$ LM111 prior to crosslinking were photocrosslinked in the same manner as compared to other groups. Samples were cored using a $6 \mathrm{~mm}$ diameter biopsy punch and frozen in Tissue-Tek ${ }^{\circledR}$ OCT compound (Sakura Finetek USA, Torrance, CA) and cryosectioned to obtain $20 \mu \mathrm{m}$ thick sections. For each gel formulation, 6-8 sections were stained with a primary antibody specific to the $\gamma$ chain of LM111 (L9393, Sigma-Aldrich, St Louis, MO), followed by a goat anti-rabbit secondary antibody (Alexa Fluor $488^{\circledR}$, Invitrogen, Carlsbad, CA). Samples were imaged by confocal microscopy to obtain three image fields per section (Zeiss LSM 510, 10× objective; Zeiss, Jena, Germany). Quantitative image analysis was performed using a custom-written MATLAB script. Briefly, images were converted to grayscale, thresholded by substracting out a blank PEG-DA image, and mean fluorescence intensity per image field was obtained as a measure of the amount of LM111 incorporated into each hydrogel. Mean intensity values were normalized to that of hydrogels containing entrapped LM111. A one-way ANOVA was performed to analyze mean fluorescence intensity per image field, using Tukey's post hoc test to detect differences between PEG-LM111 conjugates synthesized with different Ac-PEG-NHS to LM111 ratios $(P<0.05$, $n=6$ or 8 separate sections per hydrogel formulation, 3 images per section).

\subsection{Mechanical properties of PEG-LM111 hydrogels}

PEG-DA was dissolved in PEG-LM111 conjugate solution (synthesized at 25-fold molar excess Ac-PEG-NHS) and 0.1\% Irgacure $2959^{\circledR}$ solution to obtain six different hydrogel formulations (5 or $10 \%$ PEG-DA and 0,100 or $500 \mu \mathrm{g} \mathrm{ml}^{-1}$ PEG-LM111 conjugate). Hydrogel precursor solutions were injected into a custom injection mold as described above. After crosslinking, cylindrical samples $5 \mathrm{~mm}$ in diameter and $2 \mathrm{~mm}$ thick were cored and allowed to equilibrate in PBS before testing. All samples were tested in oscillatory shear in a $37^{\circ} \mathrm{C}$, temperature-controlled phosphate-buffered saline bath using a stress-controlled rheometer (AR-G2, TA Instruments, New Castle, DE). Immediately prior to testing, each gel was digitally photographed to obtain the sample diameter (average diameter $=4.7 \pm 0.6 \mathrm{~mm}$ ). Samples were placed in the center of a preheated sintered steel lower platen ( $8 \mathrm{~mm}$ diameter) and subjected to a compressive tare load $(1-2 \mathrm{~g})$ with a sintered steel upper platen ( $8 \mathrm{~mm}$ diameter). After equilibrating, samples were subjected to a $10 \%$ compressive strain followed by 20 min relaxation. Samples were subjected to an oscillatory torsional strain (1$\left.20 \mathrm{rad} \mathrm{s}^{-1}\right)$ with a maximum amplitude of shear strain $(\gamma, 0.01)$. The complex shear moduli $\left(\left|G^{*}\right|\right)$ were reported at a frequency of $10 \mathrm{rad} \mathrm{s}^{-1}$. Differences in shear moduli amongst hydrogels with varying concentrations of PEG-DA and PEG-LM111 conjugate were analyzed via two-way ANOVA with Tukey's post hoc test $(P<0.05$, $n=5$ per hydrogel formulation).

\subsection{Cell isolation and culture}

Porcine NP cells were used for study as the majority of cells isolated from the immature porcine NP are known to resemble notochordally derived NP cells [52], and are therefore useful for identifying scaffold formulations that maintain the notochordallike NP cell phenotype. Lumbar spines were obtained from pigs shortly after the animals were killed (L1-L5, 4-7 months, Nahunta Pork Outlet, Raleigh NC). Cells were isolated from the NP regions of IVDs by enzymatic digestion [56] and cultured in monolayer for 17 days in culture media (F-12 media supplemented with $5 \%$ fetal bovine serum (FBS), $10 \mathrm{mM}$ HEPES, $100 \mathrm{U} \mathrm{ml}^{-1}$ penicillin, and $100 \mathrm{U} \mathrm{ml}^{-1}$ streptomycin) prior to experiments.

\subsection{Primary NP cell behavior on PEG-LM111 hydrogels in two dimensions}

\subsection{1. sGAG production}

Primary porcine NP cells $\left(88,000\right.$ cells $\left.\mathrm{cm}^{-2}\right)$ were seeded onto PEG-LM111 hydrogels of varying concentrations of PEG (2 or $10 \%$ PEG-DA) and LM111 (0 or $1 \mathrm{mg} \mathrm{ml}^{-1}$ LM111) for a total of four hydrogel substrate formulations ( $n=6$ per substrate). PEG concentrations were chosen to form "soft" and "stiff" hydrogels, with "soft" 2\% PEG gels having similar stiffness to lamininpresenting gels previously shown to induce NP cell clustering and sGAG production [23]. Primary NP cells $\left(88,000\right.$ cells $\left.\mathrm{cm}^{-2}\right)$ were also seeded onto a laminin-rich, ECM-derived basement membrane extract (BME) product (Trevigen ${ }^{\circledR}$, Gaithersburg, MD; growth factor-reduced, $13.8 \mathrm{mg} \mathrm{ml}^{-1}$ ) as a positive control. BME is a solubilized basement membrane preparation extracted from the Engelbreth-Holm-Swarm (EHS) mouse sarcoma tumor, which contains high concentrations of several ECM proteins: LM111 ( 60\%), type IV collagen ( 30\%), entactin ( 8\%) and heparin sulfate [57]. When polymerized into a "thick" gel, BME provides a laminin-rich environment of stiffness close to that of the native NP tissue $(0.2 \mathrm{kPa})[23,27,58]$. Cells were cultured on top of each hydrogel formulation for 4 days in culture media, after which sGAG production by NP cells was analyzed with the dimethylmethylene blue (DMMB) spectrophotometric method as previously described [23]. All media overlay from culture samples was collected, while cells and gel proteins remaining in the corresponding wells after removal of media were digested in papain solution $\left(125 \mu \mathrm{g} \mathrm{ml}^{-1}\right.$ in PBS with $5 \mathrm{mM}$ EDTA and $5 \mathrm{mM}$ cysteine, $2 \mathrm{~h}, 65^{\circ} \mathrm{C}$ ). Samples from control wells that only contained gels (no cells) were collected and processed similarly to control for background sGAG content in substrates; two acellular samples were used per substrate as prior work has shown values to be highly repeatable and very low [23]. sGAG content was measured by mixing samples with DMMB dye, and absorbance $(535 \mathrm{~nm})$ was measured on a plate reader (Perkin-Elmer Enspire Multimode Reader, Waltham, MA). sGAG concentrations were calculated from a standard curve prepared from chondroitin-4-sulfate (Sigma). Total concentration of sGAG (media overlay plus cell digest) was normalized to total DNA content (Quant-iT PicoGreen dsDNA Kit, Invitrogen) for each sample. Differences in sGAG production (sGAG/DNA) across hydrogel substrate formulations were analyzed via one-way ANOVA with Tukey's post hoc analysis $(P<0.05, n=6$ per substrate formulation). 


\subsubsection{Cell morphology}

Immature porcine NP cells $\left(88,000\right.$ cells $\left.\mathrm{cm}^{-2}\right)$ were seeded onto PEG-only hydrogels (2 or 10\% PEG-DA), and PEG-LM111 hydrogels ( 2 or $10 \%$ PEG-DA, $1 \mathrm{mg} \mathrm{ml}^{-1}$ LM111) as described above ( $n=6$ per substrate formulation). The same number of NP cells were seeded onto BME gels for comparison. After 4 days of culture upon gels, NP cells were fixed with $4 \%$ paraformaldehyde (Electron Microscopy Sciences, Hatfield, PA; diluted in DPBS) for $20 \mathrm{~min}$ at room temperature. NP cells were then washed with DPBS and labeled for actin (Alexafluor-488 phalloidin, Invitrogen, $200 \times$ dilution in DPBS for 30 min at room temperature) followed by a cell nuclei stain (propidium iodide, Sigma, $0.33 \mathrm{mg} \mathrm{ml}^{-1}$ for $20 \mathrm{~min}$ at room temperature). Immediately after staining, NP cells were imaged via confocal microscopy (Zeiss LSM510, 10× magnification).

\subsection{Cell viability in PEG-LM111 hydrogels in three dimensions}

Preliminary cell encapsulation experiments were performed to evaluate PEG-LM111 conjugate bioactivity and to assess the ability of LM111 to promote NP cell survival in 3-D culture under lowcell-density, serum-free conditions. Primary porcine NP cells were encapsulated in blank PEG-DA hydrogels (6\% PEG-DA), PEG-DA hydrogels with unmodified LM111 that had been mixed in prior to crosslinking (6\% PEG-DA, $200 \mu \mathrm{g} \mathrm{ml}^{-1}$ entrapped LM111) or PEG-LM111 hydrogels (6\% PEG-DA, $200 \mu \mathrm{g} \mathrm{ml}^{-1}$ PEGylated LM111). Briefly, porcine NP cells were pelleted and resuspended in hydrogel precursor solutions ( 2 million cells $\mathrm{ml}^{-1}$ ), injected into custom injection molds and polymerized upon exposure to UV light in the presence of $0.1 \%(\mathrm{w} / \mathrm{v})$ photoinitiator (Irgacure $\left.2959^{\circledR}\right)$ as described above. After polymerization, cylindrical constructs were cored using a $6 \mathrm{~mm}$ biopsy punch and cultured in 24 well plates in serum-free media (F-12 supplemented with $10 \mathrm{mM}$ HEPES, $100 \mathrm{U} \mathrm{ml}^{-1}$ penicillin and $100 \mathrm{U} \mathrm{ml}^{-1}$ streptomycin) with gentle agitation. At each time point, cell-gel constructs $(n=5$ per formulation) were submerged in live/dead staining solution (Invitrogen) and incubated at $37^{\circ} \mathrm{C}$ for $30 \mathrm{~min}$. Cell viability and distribution were visualized by confocal microscopy on days 0 and 7. Images (four per cell-gel construct) were analyzed using Image $(\mathrm{NIH})$ to determine the percentage of live cells present at each time point. Differences in cell viability amongst hydrogel formulations were analyzed via two-way ANOVA (time point, hydrogel formulation) with Tukey's post hoc test $(P<0.05, n=5$ per hydrogel formulation).

\subsection{Primary NP cell behavior in PEG-LM111 hydrogels in three dimensions}

Primary porcine NP cells (20 million $\mathrm{ml}^{-1}$ ) were mixed with PEG-DA (5 or $10 \%)$, PEG-LM111 conjugate $\left(0,100\right.$ or $500 \mu \mathrm{g} \mathrm{ml}^{-1}$ ) and $0.1 \%$ Irgacure $2959^{\circledR}$ for a total of six material formulations. Precursor solutions were injected into custom molds and crosslinked by UV exposure ( $5 \mathrm{~min}, 3-4 \mathrm{~mW} \mathrm{~cm}^{-2}$ ). Samples were cored using a $3 \mathrm{~mm}$ biopsy punch ( $n=9$ per formulation) and cultured in vitro (F-12 media supplemented with $10 \%$ FBS, 10 mM HEPES, $100 \mathrm{U} \mathrm{ml}^{-1}$ penicillin, and $100 \mathrm{U} \mathrm{ml}^{-1}$ streptomycin) with gentle agitation. 50\% volume media changes were performed every 34 days for 28 days.

\subsubsection{Measurement of media metabolites}

Early metabolite levels have been shown to predict long-term matrix accumulation for chondrocytes in elastin-like polypeptide scaffolds [59], and were therefore measured to evaluate hydrogel formulation effects on cell metabolism. Media aliquots from NP cell-PEG samples, and media from wells containing no PEG or cells were obtained on day 4 and stored at $-80{ }^{\circ} \mathrm{C}$ until further use. On the day of analysis, media aliquots were thawed and filtered through a $10 \mathrm{kDa}$ MW cut-off centrifugal filter device (Nanosep, Pall Life Sciences, East Hills, NY). Samples $(15 \mu \mathrm{l})$ were then transferred to plastic vials, briefly spun and analyzed for glucose, lactate and pyruvate concentrations on a CMA 600 microdialysis analyzer (CMA Microdialysis, North Chelmsford, MA). The difference between each metabolite concentration in media collected from wells containing cell-laden PEG hydrogel samples and day 0 media that had been cultured for the same period was calculated for each sample. For each metabolite, differences amongst hydrogel formulations were analyzed via two-factor ANOVA (\% PEG-DA, PEGLM111 conjugate concentration) with Tukey's post hoc test $(P<0.05, n=9$ per hydrogel formulation)

\subsubsection{Phenotypic marker immunostaining}

Cell-laden hydrogel samples were immunostained for $\mathrm{N}$-cadherin, cytokeratin 8 , integrin $\alpha 3$ and integrin $\alpha 6$ to evaluate the effects of PEG-LM111 hydrogel stiffness and LM111 concentration on NP cell phenotype. On day 28 , samples $(n=3$ per formulation) were embedded in Tissue Tek $^{\circledR}$ OCT embedding compound and flash frozen in liquid nitrogen. Samples were stored at $-80{ }^{\circ} \mathrm{C}$ until further use. Frozen cell-laden PEG-LM111 hydrogel sections ( $8 \mu \mathrm{m}$ thick) were fixed in $4 \%$ paraformaldehyde (10 min at room temperature) for labeling with antibodies detecting $\mathrm{N}$-cadherin and cytokeratin 8 . For labeling integrin subunits $\alpha 3$ and $\alpha 6$, sections were fixed in acetone $\left(10 \mathrm{~min}\right.$ at $\left.-20^{\circ} \mathrm{C}\right)$. Following fixation, all sections were incubated with blocking solution $(3.75 \%$ $\mathrm{BSA} / 5 \%$ goat serum) for $45 \mathrm{~min}$ at room temperature, and then incubated for $2 \mathrm{~h}$ at room temperature with one of the following primary antibodies: N-cadherin (ab12221, Abcam, Cambridge, MA), cytokeratin 8 (SM3079P, Acris Antibodies, San Diego, CA), integrin $\alpha 3$ (AB1920, EMD Millipore, Billerica, MA) and integrin a6 (555734, BD Biosciences, San Jose, CA). Sections were washed twice with PBS and incubated with secondary antibody (AlexaFluor 488, Molecular Probes, Eugene, OR) for $30 \mathrm{~min}$ in blocking solution. Control sections were incubated with appropriate $\operatorname{IgG}$ controls or secondary antibody alone as a negative control for polyclonal antibodies. All sections were counterstained with propidium iodide (Sigma) at room temperature for $30 \mathrm{~min}$ to label cell nuclei. Sections were imaged via confocal microscopy (Zeiss, $20 \times$ NA 0.5 objective). Digital images acquired for each cell-laden hydrogel ( $n=9$ images per hydrogel formulation) were evaluated by two blinded graders coming to consensus for fluorescence staining uniformity with the following ordinal scale: 0 (no stain), 1 ( $<10 \%$ cells positively stained), 2 ( $10-50 \%$ cells positively stained), 3 ( $>50 \%$ of cells positively stained) for each image. Grades of immunohistochemical staining were analyzed for differences amongst hydrogel formulations using Kruskal-Wallis one-way ANOVA $(P<0.05)$. When significance was observed, post hoc Wilcoxon tests with Bonferroni correction for multiple comparisons were performed to detect differences amongst hydrogel formulations.

\section{Results}

\subsection{LM111 distribution in PEG-LM111 hydrogels}

Immunostaining of PEG hydrogels was performed to determine the effect of the Ac-PEG-NHS to LM111 ratio used in the PEGylation reaction on the amount of LM111 incorporated into each hydrogel formulation. Immunostaining results demonstrate that the ratio of PEG to LM111 used in PEG-LM111 conjugate synthesis affects the amount of LM111 incorporated into the hydrogel (Fig. 2). Fluorescence images show more intense staining for LM111 in hydrogels containing PEG-LM111 conjugate synthesized with a high AcPEG-NHS PEG to LM111 ratio (500:1) as compared to those containing PEG-LM111 conjugates synthesized with a low ratio 
A

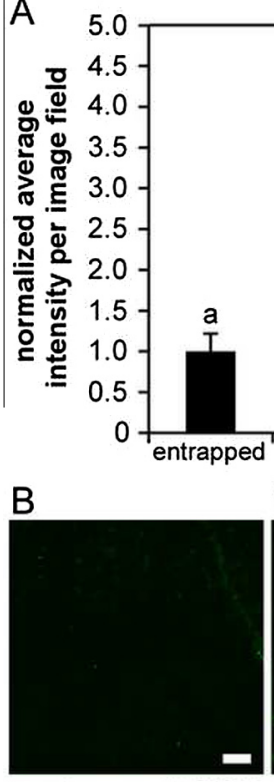

entrapped LM111

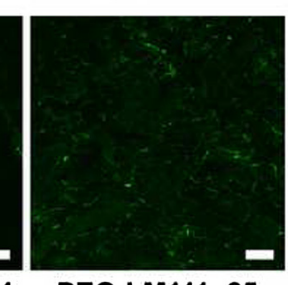

PEG:LM111=25

Fig. 2. Immunostaining of PEG-LM111 hydrogels. (A) Mean fluorescence intensity per image field in PEG hydrogels containing entrapped LM111, or PEG-LM111 hydrogels containing PEG-LM111 conjugates synthesized with various Ac-PEG-NHS to LM111 ratios. Fluorescence intensity increased with increasing molar excess of Ac-PEG-NHS:LM111 ratio in the PEG-LM111 conjugate synthesis reaction (mean \pm SEM, $n=6$ sections, 3 images per section, conditions labeled with different letters significantly different, $P<0.03$ ). (B) Representative images of LM111 immunostaining in PEG hydrogels. Scale bars $=100 \mu \mathrm{m}$.

of Ac-PEG-NHS to LM111 (25:1) or physically entrapped LM111 (Fig. 2B). Mean fluorescence intensity per image field significantly increased with increasing molar excess Ac-PEG-NHS in PEG-LM111 conjugate synthesis (ANOVA, $P<0.03$ ). Very high levels of PEGylation $(500: 1)$ resulted in $\sim 3.5$ times more intense staining for LM111 in PEG-based hydrogels, as compared to PEG-DA hydrogels containing entrapped unmodified LM111; however, this degree of LM111 modification has been shown to inhibit NP cell adhesion to the PEGylated protein [46]. Therefore, PEG-LM111 conjugate synthesized with a low molar excess Ac-PEG-NHS (25:1) was utilized in all subsequent cell-entrapment studies.

\subsection{PEG-LM111 hydrogel mechanical properties}

PEG-LM111 hydrogels were tested in oscillatory torsional shear to investigate the effects of PEG-LM111 conjugate concentration and PEG-DA concentration on hydrogel mechanical properties. Photocrosslinked PEG-LM111 hydrogel stiffness $\left(\left|G^{*}\right|\right)$ significantly increased with increasing PEG-LM111 conjugate concentration for gels formed with either 5\% or 10\% PEG-DA (two-way ANOVA, $P<0.03$ ) (Fig. 3). PEG-LM111 hydrogel stiffnesses $\left(\left|G^{*}\right|\right)$ were significantly higher in gels containing 10\% PEG-DA as compared to 5\% PEG-DA (two-way ANOVA, $P<0.001$ ).

\subsection{Primary NP cell behavior on PEG-LM111 hydrogels in two dimensions}

To determine if immature NP cells form multicell clusters and synthesize ECM on PEG-LM111 hydrogel substrates, primary NP cells were seeded on PEG-LM111 hydrogels containing $1 \mathrm{mg} \mathrm{ml}^{-1}$ LM111 and varying concentrations of PEG (2 or 10\%). NP cells seeded on soft, PEG-LM111 hydrogels containing low amounts of PEG synthesized similar levels of sGAG as compared to cells plated

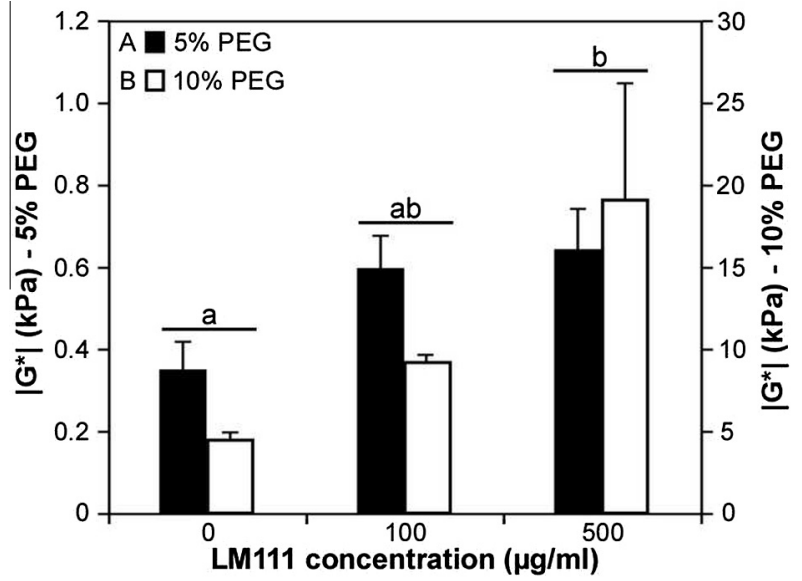

Fig. 3. Physical characterization of photocrosslinked PEG-LM111 hydrogels. Torsional shear stiffness $\left(\left|G^{*}\right|, 5 \mathrm{rad} \mathrm{s}^{-1}\right)$ of $5 \%(\mathrm{w} / \mathrm{v})$ and $10 \%$ PEG $(\mathrm{w} / \mathrm{v})$ hydrogels (mean \pm SEM, $n=5$, conditions labeled with different letters significantly different, $P<0.03)$.

on laminin-containing, polymerized BME substrates (one-way ANOVA, Tukey's post hoc test, $P>0.05$ ) (Fig. 4A). Primary NP cells seeded onto PEG-LM111 hydrogel substrates containing high amounts of PEG synthesized significantly less sGAG (Tukey's post hoc test, $P<0.0001$ ), with total sGAG production similar to that of cells seeded onto PEG hydrogels containing no protein.

Over 4 days in culture, primary NP cells were found to form large, multicell clusters when seeded on PEG-LM111 hydrogels containing low concentrations of PEG (2\%) or polymerized BME substrates (Fig. 4B). In contrast, NP cells seeded on PEG-LM111 substrates containing high concentrations of PEG (10\%) or PEGonly substrates (no LM111) remained attached as single cells with uniform distribution.

\subsection{Cell viability in 3-D PEG-LM111 hydrogels}

To verify the bioactivity of crosslinked PEG-LM111 conjugate, and to assess the ability of LM111 to promote NP cell survival in 3-D PEG hydrogels under low-cell-density, serum-free conditions, primary porcine NP cells were entrapped in PEG-DA hydrogels containing the same concentration of PEG-LM111 conjugate or entrapped unmodified LM111 and cultured for 7 days. Cells remained

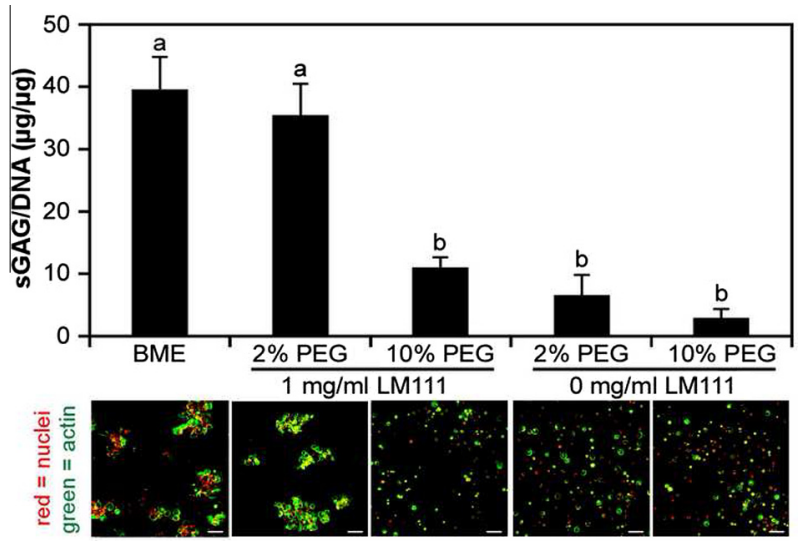

Fig. 4. NP cell clustering and sGAG synthesis on PEG-LM111 hydrogels. Immature porcine NP cells were cultured on top of laminin-rich basement membrane extract (BME), PEG-LM111 hydrogels and PEG-only hydrogels for 4 days. NP cells clustered (bottom) and synthesized higher amounts of sGAG (top) on BME and PEG-LM111 substrates containing 2\% PEG and $1 \mathrm{mg} \mathrm{ml}^{-1}$ LM111 (mean \pm SEM, $n=5$, conditions labeled with different letters significantly different, $P<0.0001$ ). Scale bars $=100 \mu \mathrm{m}$. 
viable through photocrosslinking, with $>82 \%$ cell viability for all hydrogel formulations on day 0 . Cell viability was significantly lower after 7 days in culture for all hydrogel formulations $(P<0.001)$; however, NP cell survival on day 7 was significantly higher in PEG hydrogels containing entrapped LM111 or PEGLM111 conjugate as compared to blank PEG-DA gels (Tukey's post hoc test, $P<0.02$ ) (Fig. 5).

\subsection{Primary NP cell behavior in 3-D PEG-LM111 hydrogels}

Media aliquots from NP cell-laden PEG-LM111 hydrogels were analyzed for glucose, lactate and pyruvate to evaluate the effects of hydrogel stiffness and LM111 concentration on NP cell metabolism. Lactate and pyruvate levels were significantly affected by PEG-LM111 conjugate concentration (two-way ANOVA, $P<0.001$ ); however, glucose consumption was similar for all material formulations. Cells cultured in gels containing $100 \mu \mathrm{g} \mathrm{ml}^{-1}$ PEG-LM111 conjugate consumed more pyruvate and produced more lactate over the 4 day culture period than cells cultured in gels containing 0 or $500 \mu \mathrm{g} \mathrm{ml}^{-1}$ PEG-LM111 conjugate (Fig. 6).

Cytokeratin $8, \mathrm{~N}$-cadherin, integrin $\alpha 3$ and integrin $\alpha 6$ expression by NP cells cultured in PEG-LM111 hydrogels was evaluated by immunohistochemical analysis (Table 2, Fig. 7). The percentage of cells staining positively for cytokeratin 8 was significantly higher in softer PEG-LM111 gels containing 5\% PEG and 100 or $500 \mu \mathrm{g} \mathrm{ml}^{-1}$ LM111 (one-way ANOVA, Bonferroni correction, $P<0.004)$ as compared to stiffer gels containing 10\% PEG and equivalent amounts of LM111, and PEG-only (no LM111) gels. Ncadherin expression was significantly higher for NP cells cultured in PEG-LM111 hydrogels containing 5\% PEG and high concentrations of LM111 $\left(500 \mu \mathrm{g} \mathrm{ml}^{-1}\right.$ ) (one-way ANOVA, Bonferroni correction, $P<0.004)$ as compared to cells cultured in all other hydrogel formulations. Integrin $\alpha 3$ expression varied significantly with hydrogel formulation $(P<0.0001)$ with the highest

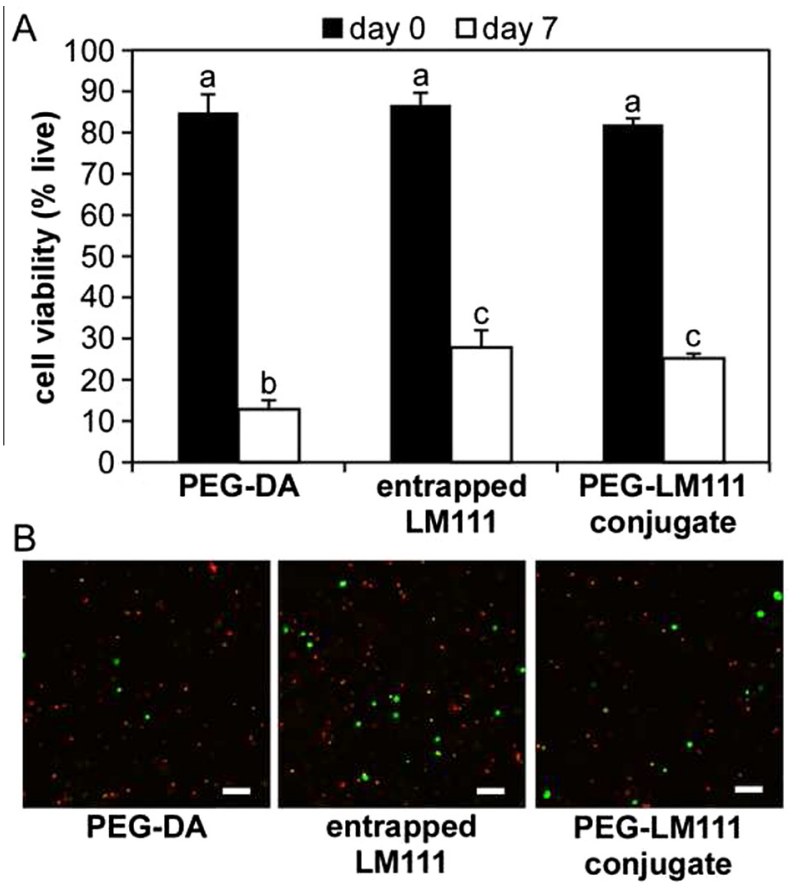

Fig. 5. Cell viability in PEG hydrogels. (A) NP cell viability in PEG-based hydrogels after 0 and 7 days of culture in serum-free media. Percent viability determined by counting the number of live cells as a percentage of total cells in images of hydrogels stained with live/dead viability assay (mean \pm SEM, $n=5$, conditions labeled with different letters significantly different, $P<0.02$ ). (B) Representative images of live/dead stained cell-laden hydrogels, where live cells fluoresce green and dead cells fluoresce red. Scale bars $=100 \mu \mathrm{m}$.

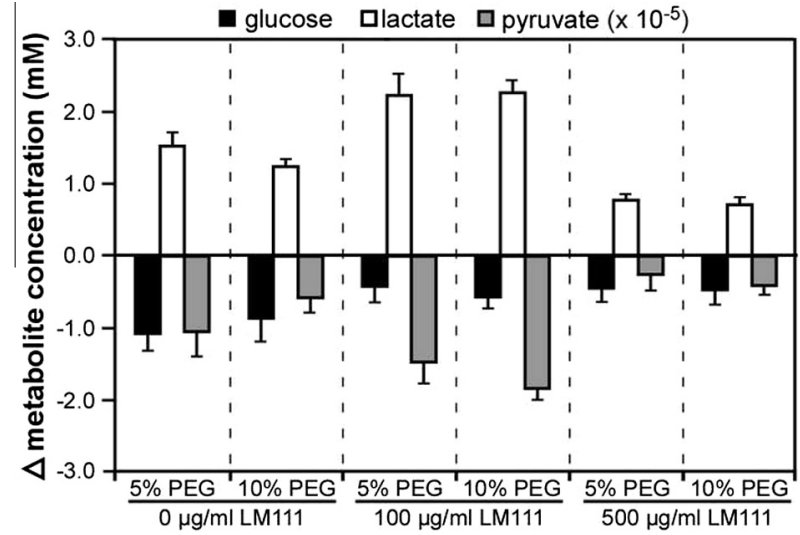

Fig. 6. Media metabolite concentrations (change from day 0 media) in media aliquots obtained from NP cell-PEG constructs. Cells in gels containing $100 \mu \mathrm{g} \mathrm{ml}^{-1}$ LM111 consumed significantly more pyruvate and produced significantly more lactate than cells in all other hydrogel formulations (mean \pm SEM, $n=9, P<0.01$ ).

Table 2

Frequency of phenotypic marker immunohistochemical scores for NP cell-laden hydrogels of varying formulations.

\begin{tabular}{lllllll}
\hline \multicolumn{2}{l}{ N-Cadherin } & \multicolumn{1}{l}{} \\
\hline \multirow{2}{*}{ Score } & $5 \%$ PEG & $10 \%$ PEG & $5 \%$ PEG & $10 \%$ PEG & $5 \%$ PEG $^{\text {a }}$ & $10 \%$ PEG \\
\cline { 2 - 7 } & $0 \mu \mathrm{g} \mathrm{ml}^{-1}$ & LM111 & $100 \mu \mathrm{g} \mathrm{ml}^{-1}$ LM111 & $500 \mu \mathrm{g} \mathrm{ml}^{-1}$ LM111 \\
\hline 0 & 4 & 0 & 6 & 4 & 0 & 6 \\
1 & 5 & 8 & 1 & 4 & 1 & 3 \\
2 & 0 & 1 & 2 & 0 & 4 & 0 \\
3 & 0 & 0 & 0 & 0 & 4 & 0
\end{tabular}

\begin{tabular}{lllllll}
\hline \multicolumn{6}{l}{ Cytokeratin 8} \\
\hline Score & $5 \%$ PEG & $10 \%$ PEG & $5 \%$ PEG $^{\text {b }}$ & $10 \%$ PEG & $5 \%$ PEG $^{\text {b }}$ & $10 \%$ PEG \\
\cline { 2 - 7 } & $0 \mu \mathrm{g} \mathrm{ml}^{-1}$ & LM111 & $100 \mu \mathrm{g} \mathrm{ml}^{-1}$ & LM111 & $500 \mu \mathrm{g} \mathrm{ml}^{-1}$ LM111 \\
\hline 0 & 0 & 0 & 0 & 0 & 0 & 0 \\
1 & 7 & 6 & 1 & 6 & 0 & 8 \\
2 & 2 & 3 & 2 & 3 & 4 & 1 \\
3 & 0 & 0 & 6 & 0 & 5 & 0
\end{tabular}

\begin{tabular}{lllllll}
\hline \multicolumn{2}{l}{ Integrin $\alpha 3$} & & & & \\
\hline \multirow{2}{*}{ Score } & $5 \%$ PEG & $10 \%$ PEG & $5 \%$ PEG $^{\text {c }}$ & $10 \%$ PEG & $5 \%$ PEG $^{\text {d }}$ & $10 \%$ PEG \\
\cline { 2 - 7 } & $0 \mu \mathrm{g} \mathrm{ml}^{-1}$ & LM111 & $100 \mu \mathrm{g} \mathrm{ml}^{-1}$ & LM111 & $500 \mu \mathrm{g} \mathrm{m}^{-1}$ & LM111 \\
\hline 0 & 1 & 0 & 0 & 0 & 0 & 0 \\
1 & 5 & 7 & 0 & 4 & 1 & 4 \\
2 & 0 & 2 & 1 & 3 & 4 & 5 \\
3 & 0 & 0 & 8 & 2 & 4 & 0
\end{tabular}

a Significantly different from hydrogels containing 5\% PEG $\left(0\right.$ or $100 \mu \mathrm{g} \mathrm{ml}^{-1}$ LM111) and formulations containing $10 \%$ PEG $\left(0,100\right.$ or $\left.500 \mu \mathrm{g} \mathrm{m}^{-1}\right)(P<0.004)$. b Significantly different from formulations containing $10 \%$ PEG $(0,100$ or $500 \mu \mathrm{g} \mathrm{ml}^{-1}$ LM111) and hydrogels containing 5\% PEG $\left(0 \mu \mathrm{g} \mathrm{ml}^{-1}\right.$ LM111) $(P<0.004)$.

Significantly different from formulations containing 5\% PEG $\left(0 \mu \mathrm{g} \mathrm{ml}^{-1} \mathrm{LM} 111\right)$ and $10 \%$ PEG ( 0 or $500 \mu \mathrm{g} \mathrm{ml}^{-1}$ LM111) $(\mathrm{P}<0.004)$.

d Significantly different from formulations containing $5 \%\left(0 \mu \mathrm{g} \mathrm{ml}^{-1}\right.$ LM111) or 10\% PEG $\left(0 \mu \mathrm{g} \mathrm{ml}^{-1} \mathrm{LM} 111\right)(P<0.004)$

percentage of cells staining positively for cells cultured in PEGLM111 gels containing 5\% or $10 \%$ PEG and $100 \mu \mathrm{g} \mathrm{ml}^{-1} \mathrm{LM} 111$, or $5 \%$ PEG and $500 \mu \mathrm{g} \mathrm{ml}^{-1}$ LM111. Very low or no staining of integrin $\alpha 6$ was observed for all hydrogel formulations.

\section{Discussion}

The goal of this work was to develop a laminin-functionalized hydrogel with tunable mechanical properties and to evaluate the 


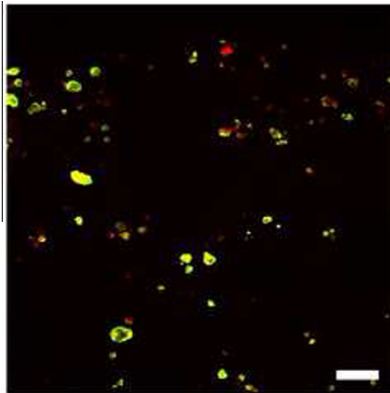

cytokeratin 8

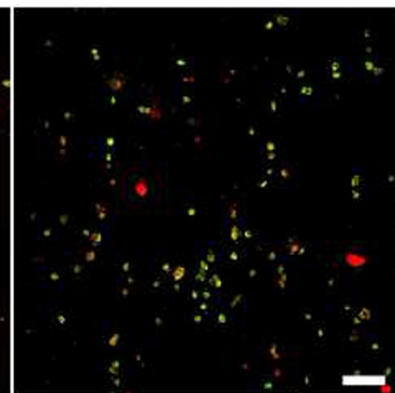

$\mathrm{N}$-cadherin

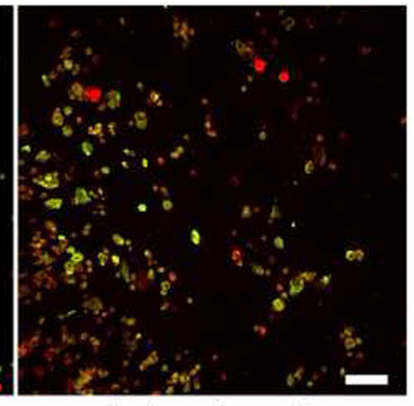

integrin $\alpha 3$

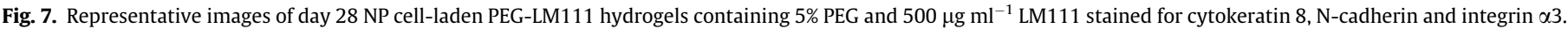
Scale bar $=50 \mu \mathrm{m}$.

effects of matrix stiffness and LM111 ligand concentration on immature NP cell phenotype in vitro. Previous work has shown that BME-polymerized gels or soft BME upon polyacrylamide promote formation of multicell clusters for cultured primary disc cells $[23,60]$. While polyacrylamide substrates systems are useful for 2D studies, they are not suitable for cell entrapment and 3-D cell culture; therefore, we engineered a biomaterial by attaching LM111 to PEG-based hydrogels, as PEG is non-cytotoxic, nonfouling, and has a long history of clinical use as a drug delivery agent for therapeutic proteins [61]. In addition, the mechanical properties of PEG hydrogels formed by UV photopolymerization of PEG-DA can be easily manipulated [40]. Results reveal that specific formulations of the PEG-LM111 hydrogel appear to preserve features of the immature NP cell phenotype.

Increasing the degree of LM111 PEGylation (ratio of Ac-PEGNHS to LM111 in the PEGylation reaction) was shown to significantly increase the amount of LM111 incorporated into PEG-LM111 hydrogels. While increased ligand density within PEG-LM111 hydrogels is desirable, our previous work has shown that a high degree of LM111 modification by Ac-PEG-NHS significantly reduces its bioactivity and inhibits immature NP cell adhesion to the modified protein [46]. Therefore, PEG-LM111 conjugates synthesized at low molar ratios of Ac-PEG-NHS to LM111 (25:1) were utilized in all subsequent experiments. Characterization of the bulk mechanical properties of PEG-LM111 hydrogels showed that PEG concentration $(\% \mathrm{w} / \mathrm{v})$ was a dominant variable in determining the stiffness of PEG-LM111 hydrogels, with dynamic stiffness values for gels containing 10\% PEG an order of magnitude higher than those of gels formed with 5\% PEG. This was expected since increasing the polymer concentration results in an increased number of polymer chains in the hydrogel, thereby increasing the number of entanglements in the gel. PEG-LM111 hydrogel stiffness, however, could not be completely decoupled from ligand concentration, as increasing the amount of PEGLM111 conjugate also increased PEG-LM111 hydrogel stiffness for gels containing both 5\% and 10\% PEG. This finding differs from that of a recent study, in which increasing the amount of LM111 conjugate in PEG-DA hydrogels was reported to significantly decrease hydrogel stiffness [45]. Our finding may be related to the PEG-LM111 conjugate having an increased degree of modification by the addition of PEG onto LM111, thereby increasing the number of acrylate groups on LM111 that can participate in the photocrosslinking reaction. This feature may reduce the likelihood that a single PEGylated LM111 molecule can result in chain termination. The inability to independently tune the dynamic stiffness and LM111 concentration of PEG-LM111 hydrogels demonstrates a limitation of the PEG photocrosslinking system for evaluating the effects of matrix stiffness and ligand concentration on cell behaviors. However, since PEG-LM111 hydrogel stiffness is largely controlled by the total PEG concentration of the gel, this is a useful system for furthering our understanding of ECM stiffness and composition on NP cell phenotype.

Dynamic shear moduli of photocrosslinked PEG-LM111 hydrogels were found to be approximately $10 \times$ higher than that of injectable PEG-LM111 hydrogels formed by a Michael-type addition reaction [46], despite having the same total PEG and LM111 concentrations. This is likely due to differences in the molecular weight of functionalized PEG molecules used to form the two different hydrogels, and intrinsic differences between the different crosslinking systems. PEG-LM111 hydrogel dynamic shear moduli can be tuned within the range of values previously reported for non-degenerate human NP (7-21 kPa) [62] by altering both the total PEG concentration and PEG-LM111 conjugate concentration, with hydrogel stiffness being dominated by the former. Human NP dynamic shear moduli have been shown to increase significantly with age and grade of degeneration, up to $60 \mathrm{kPa}$ [63], values which could be achieved in the PEG-LM111 hydrogel system by increasing the total PEG concentration. While PEG-LM111 hydrogel dynamic shear values closely match that of the human $\mathrm{NP}$, phase angle $(\delta)$ values were more characteristic of an elastic material $\left(\delta=0.9-8.2^{\circ}\right)$ as compared the human NP $\left(\delta=23-31^{\circ}\right)$ [58]. Overall, these finding suggests that PEG-LM111 hydrogels can be formulated to match certain NP tissue mechanical properties; however, they may have reduced capacity to dissipate energy in comparison to the native NP.

While 2-D studies afford very good control of the substrate stiffness and ECM chemistry, culturing cells within a 3-D matrix is much more representative of the native environment. As expected, the majority of primary NP cells encapsulated in PEG-based hydrogels at a very low cell density and cultured under serum-free conditions died over 7 days in culture; however, significantly more cells survived when encapsulated in hydrogels containing LM111 as compared to PEG-only gels. It is well known that LM111 promotes cell survival for a number of cell types in vitro [19]; therefore, this finding suggests that LM111 may be a survival ligand for primary NP cells. Viability was similar for cells cultured in PEG-LM111 hydrogels and PEG hydrogels containing an equal concentration of entrapped, unmodified LM111. This finding suggests that PEGylated LM111 retains the bioactivity of the native protein in three dimensions, and that survival is mediated by cell-LM111 interactions irrespective of ligand presentation. Overall, cell viability was likely affected by the small mesh size of PEG hydrogels formed by photopolymerizing PEG-DA, which limits nutrient and waste diffusion in cultured hydrogels [64], and may inhibit cellcell interactions when cells are encapsulated at very low densities. For primary NP cells cultured within 3-D PEG-LM111 hydrogels of varying stiffnesses and LM111 ligand concentration, media metabolite concentrations suggest that LM111 ligand density, but not stiffness of the material, has a significant effect on NP cell metabolism, particularly lactate production. NP cells rely on diffusion of 
nutrients such as oxygen and glucose from the cartilaginous end plates; most of their energy is formed by the conversion of glucose to lactic acid; however, NP cells do require oxygen to function [6567]. Interestingly, despite increased lactate production and pyruvate consumption by cells cultured in PEG-LM111 gels containing low concentrations of LM111, glucose consumption by NP cells remained low across all hydrogel formulation. It is important to note that hydrogels were cultured under normoxic conditions, which may have led to increased oxygen consumption and reduced glycolysis by entrapped cells. Increased lactate concentrations in scaffold-chondrocyte cultures at early time points has been shown to be a strong predictor of glycosaminoglycan and hydroxyproline accumulation in chondrocytes [59], suggesting that low levels of LM111 may improve matrix production in PEG scaffolds.

Although it has been hypothesized that promoting or maintaining a notochordal-like immature NP cell phenotype may be important for tissue engineering strategies aimed at NP regeneration, there has been limited assessment of the effects of scaffold design on cell phenotype. This is in part due to the lack of specific markers that distinguish immature, notochordal NP cells from small, more chondrocyte-like NP cells, as well as from articular chondrocytes and anulus fibrosus cells. Recently, numerous studies have focused on markers uniquely expressed in the immature or non-degenerate $\mathrm{NP}$, and suggest integrin $\alpha 3$ [17], integrin $\alpha 6[17,52], \mathrm{N}$-cadherin $[50,53]$ and cytokeratin $8[48,50]$ as potential NP phenotypic markers. Here, N-cadherin was found to be highly expressed when immature NP cells were cultured in soft, PEG-LM111 hydrogels containing 5\% PEG and high concentrations of LM111 $\left(500 \mu \mathrm{g} \mathrm{ml}^{-1}\right)$, characteristic of a soft hydrogel with high LM111 ligand density. Cytokeratin 8 is known to be highly expressed in the human notochord [54] and immature porcine NP [48], and was higher for NP cells cultured in PEG-LM111 gels containing 5\% PEG and either low $\left(100 \mu \mathrm{g} \mathrm{ml}^{-1}\right)$ or high $\left(500 \mu \mathrm{g} \mathrm{ml}^{-1}\right)$ amounts of LM111. This is in contrast to the findings for PEG-LM111 hydrogels formed from 10\% PEG or PEG-only (no LM111). The findings for higher N-cadherin and cytokeratin 8 expression in LM111 containing PEG gels of $5 \%$ PEG suggests that soft ( $<1 \mathrm{kPa}$ ), LM111-functionalized gels may lead to maintenance of this key feature of immature NP cell phenotype. NP cells were found to express varying levels of integrin $\alpha 3$ across hydrogel formulations; however, very little immunostaining for integrin $\alpha 6$ was observed for all cell-laden constructs. This was unexpected since porcine NP cells have previously been shown to attach to LM111 via integrin $\alpha 6$ [16], while adult human NP cells make use of $\alpha 3, \alpha 5$ and $\beta 1$ subunits to attach to LM111 [21]. Integrin $\alpha 3$ has been shown to be expressed in the immature human and porcine NP, but not in the adjacent anulus fibrosus [17], and to play a functional role in human NP cell adhesion to laminins [21]. In this study, integrin $\alpha 3$ expression was highest for primary NP cells cultured in PEGLM111 hydrogels that contained 5\% PEG and either 100 or $500 \mu \mathrm{g} \mathrm{ml}^{-1}$ LM111; however, moderate expression was observed for cells cultured in the stiffer gels containing similar amounts of LM111. This finding may reflect that NP cell-LM111 interactions are mediated at least in part by the integrin $\alpha 3$ subunit when attaching to the modified PEG-LM111 conjugate. Taken together, immunostaining of NP cell-laden PEG-LM111 hydrogels suggest that soft, LM111 functionalized hydrogels may promote both cell-cell and cell-matrix interactions characteristic of an immature NP cell phenotype.

In addition to expression of specific phenotypic markers, immature NP are differentiated from other cells in the disc by their distinct morphology, appearing as large, highly vacuolated cells arranged in multicell clusters. In a prior study, immature NP cells seeded onto polymerized BME substrates formed large, multicell clusters and synthesized high levels of sGAG as compared to other ECM protein-coated 2-D rigid substrates [23]. In the present study, immature primary NP behavior on softer, PEG-LM111 substrates was found to correlate closely to that of NP cells seeded onto BME gels, with cells seeded onto softer, PEG-LM111 hydrogels with low levels of PEG and high concentrations of LM111 found to cluster and to synthesize higher levels of SGAG, as compared to cells seeded onto blank PEG-only or stiffer, PEG-LM111 hydrogels. Hydrogel formulations tested in 2-D studies differed from those evaluated in 3-D studies, which inhibits our ability to draw clear relationships between these experiments; however the goal of this work was not to compare 2-D and 3-D situations, as those have long been known to induce very different phenotypes in cells [68]. Overall, this finding suggests that specific formulations of the PEG-LM111 hydrogel are able to mimic the physical and biochemical properties of polymerized BME previously shown to promote an immature NP cell phenotype.

\section{Conclusions}

We report here on the development and characterization of a photocrosslinkable LM111-functionalized hydrogel with tunable mechanical properties for evaluating the effects of matrix stiffness and LM111 concentration on NP cell behaviors in both two and three dimensions. In two dimensions, the softer, LM111-presenting hydrogels were found to promote primary NP cell clustering and increased levels of sGAG production as compared to stiffer LM111 presenting and PEG-only gels. In three dimensions, hydrogel formulation was found to influence NP cell metabolism and expression of proposed phenotypic markers, with higher expression of N-cadherin and cytokeratin 8 observed for cells cultured in softer $(<1 \mathrm{kPa})$, LM111-functionalized PEG-LM111. Overall, these findings suggest that softer, LM111-functionalized scaffolds may promote or maintain an immature NP cell phenotype, and that incorporation of the LM111 ligand into scaffolds might be useful for studies aimed at NP regeneration. In future work, soft PEGLM111 hydrogels (total PEG concentration $\leqslant 5 \%$ ) containing high concentrations of LM111 ( $\geqslant 500 \mu \mathrm{g} \mathrm{ml}^{-1}$ ) will be evaluated as tissue engineered scaffolds for NP replacement.

\section{Acknowledgements}

This work was completed with support from NIH Grants R01AR047442, R01EB002263, R01AR057410 and T32GM008555.

\section{Appendix A. Figures with essential colour discrimination}

Certain figures in this article, particularly Figs. 2,4,5,7, are difficult to interpret in black and white. The full colour images can be found in the on-line version, at http://dx.doi.org/10.1016/ j.actbio.2013.11.013.

\section{References}

[1] Owens PL, Woeltje M, Mutter R. Emergency Department Visits and Inpatient Stays Related to Back Problems, 2008: Statistical Brief \# 105. Healthcare Cost and Utilization Project (HCUP) Statistical Briefs. Rockville, MD, 2006.

[2] Antoniou J, Steffen T, Nelson F, Winterbottom N, Hollander AP, Poole RA, et al. The human lumbar intervertebral disc-evidence for changes in the biosynthesis and denaturation of the extracellular matrix with growth, maturation, ageing, and degeneration. J Clin Invest 1996:98:996-1003.

[3] Buckwalter JA. Aging and degeneration of the human intervertebral disc. Spine (Phila Pa 1976) 1995;20:1307-14.

[4] Boos N, Weissbach S, Rohrbach $H$, Weiler C, Spratt KF, Nerlich AG. Classification of age-related changes in lumbar intervertebral discs: 2002 Volvo Award in basic science. Spine (Phila Pa 1976) 2002;27:2631-44.

[5] Lyons G, Eisenstein SM, Sweet MBE. Biochemical-changes in intervertebraldisk degeneration. Biochim Biophys Acta 1981;673:443-53.

[6] Urban JP, Roberts S. Degeneration of the intervertebral disc. Arthritis Res Ther $2003 ; 5: 120-30$. 
[7] Trout JJ, Buckwalter JA, Moore KC, Landas SK. Ultrastructure of the human intervertebral-disk. 1. Changes in Notochordal cells with age. Tissue Cell 1982;14:359-69.

[8] Rufai A, Benjamin M, Ralphs JR. The development of fibrocartilage in the rat intervertebral disc. Anat Embryol 1995;192:53-62.

[9] Choi KS, Cohn MJ, Harfe BD. Identification of nucleus pulposus precursor cells and notochordal remnants in the mouse: implications for disk degeneration and chordoma formation. Dev Dyn 2008;237:3953-8.

[10] Hayes AJ, Benjamin M, Ralphs JR. Role of actin stress fibres in the development of the intervertebral disc: cytoskeletal control of extracellular matrix assembly. Dev Dyn 1999;215:179-89.

[11] Hunter CI, Matyas JR, Duncan NA. The functional significance of cell clusters in the notochordal nucleus pulposus: survival and signaling in the canine intervertebral disc. Spine (Phila Pa 1976) 2004;29:1099-104.

[12] Aguiar DJ, Johnson SL, Oegema TR. Notochordal cells interact with nucleus pulposus cells: regulation of proteoglycan synthesis. Exp Cell Res 1999;246:129-37.

[13] Boyd LM, Chen J, Kraus VB, Setton LA. Conditioned medium differentially regulates matrix protein gene expression in cells of the intervertebral disc Spine 2004;29:2217-22.

[14] Erwin WM, Inman RD. Notochord cells regulate intervertebral disc chondrocyte proteoglycan production and cell proliferation. Spine (Phila Pa 1976) 2006:31:1094-9.

[15] Korecki CL, Taboas JM, Tuan RS, Iatridis JC. Notochordal cell conditioned medium stimulates mesenchymal stem cell differentiation toward a young nucleus pulposus phenotype. Stem Cell Res Ther 2010;1:18.

[16] Gilchrist CL, Chen J, Richardson WJ, Loeser RF, Setton LA. Functional integrin subunits regulating cell-matrix interactions in the intervertebral disc. J Orthop Res 2007;25:829-40.

[17] Chen J, Jing L, Gilchrist CL, Richardson WJ, Fitch RD, Setton LA. Expression of laminin isoforms, receptors, and binding proteins unique to nucleus pulposus cells of immature intervertebral disc. Connect Tissue Res 2009;50:294-306.

[18] Nettles DL, Richardson WJ, Setton LA. Integrin expression in cells of the intervertebral disc. J Anat 2004;204:515-20.

[19] Ekblom P, Lonai P, Talts JF. Expression and biological role of laminin-1. Matrix Biol 2003;22:35-47.

[20] Miner JH, Yurchenco PD. Laminin functions in tissue morphogenesis. Annu Rev Cell Dev Biol 2004;20:255-84

[21] Bridgen DT, Gilchrist CL, Richardson WJ, Isaacs RE, Brown CR, Yang KL, et al. Integrin-mediated interactions with extracellular matrix proteins for nucleus pulposus cells of the human intervertebral disc. J Orthop Res 2013;10:1661-7.

[22] Gilchrist CL, Francisco AT, Plopper GE, Chen J, Setton LA. Nucleus pulposus cellmatrix interactions with laminins. Eur Cell Mater 2011;21:523-32.

[23] Gilchrist CL, Darling EM, Chen J, Setton LA. Extracellular matrix ligand and stiffness modulate immature nucleus pulposus cell-cell interactions. PLoS One 2011;6:e27170.

[24] O'Halloran DM, Pandit AS. Tissue-engineering approach to regenerating the intervertebral disc. Tissue Eng 2007;13:1927-54.

[25] Crevensten G, Walsh AJ, Ananthakrishnan D, Page P, Wahba GM, Lotz JC, et al Intervertebral disc cell therapy for regeneration: mesenchymal stem cell implantation in rat intervertebral discs. Ann Biomed Eng 2004;32:430-4.

[26] Nesti LJ, Li WJ, Shanti RM, Jiang YJ, Jackson W, Freedman BA, et al. Intervertebral disc tissue engineering using a novel hyaluronic acidnanofibrous scaffold (HANFS) amalgam. Tissue Eng Part A 2008;14:1527-37.

[27] Cloyd JM, Malhotra NR, Weng L, Chen W, Mauck RL, Elliott DM. Material properties in unconfined compression of human nucleus pulposus, injectable hyaluronic acid-based hydrogels and tissue engineering scaffolds. Eur Spine J 2007:16:1892-8.

[28] Gruber HE, Leslie K, Ingram J, Norton HJ, Hanley EN. Cell-based tissue engineering for the intervertebral disc: in vitro studies of human disc cell gene expression and matrix production within selected cell carriers. Spine J 2004:4:44-55.

[29] Sakai D, Mochida J, Iwashina T, Watanabe T, Suyama K, Ando K, et al. Atelocollagen for culture of human nucleus pulposus cells forming nucleus pulposus-like tissue in vitro: influence on the proliferation and proteoglycan production of HNPSV-1 cells. Biomaterials 2006;27:346-53.

[30] Mizuno H, Roy AK, Vacanti CA, Kojima K, Ueda M, Bonassar LJ. Tissueengineered composites of anulus fibrosus and nucleus pulposus fo intervertebral disc replacement. Spine (Phila Pa 1976) 2004;29:1290-7. discussion $7-8$.

[31] Bowles RD, Gebhard HH, Hartl R, Bonassar LJ. Tissue-engineered intervertebral discs produce new matrix, maintain disc height, and restore biomechanical function to the rodent spine. Proc Natl Acad Sci USA 2011;108:13106-11.

[32] Roughley P, Hoemann C, DesRosiers E, Mwale F, Antoniou J, Alini M. The potential of chitosan-based gels containing intervertebral disc cells for nucleus pulposus supplementation. Biomaterials 2006;27:388-96.

[33] Richardson SM, Hughes N, Hunt JA, Freemont AJ, Hoyland JA. Human mesenchymal stem cell differentiation to NP-like cells in chitosanglycerophosphate hydrogels. Biomaterials 2008;29:85-93.

[34] Dang JM, Sun DD, Shin-Ya Y, Sieber AN, Kostuik JP, Leong KW. Temperatureresponsive hydroxybutyl chitosan for the culture of mesenchymal stem cells and intervertebral disk cells. Biomaterials 2006;27:406-18.

[35] Collin EC, Grad S, Zeugolis DI, Vinatier CS, Clouet JR, Guicheux JJ, et al. An injectable vehicle for nucleus pulposus cell-based therapy. Biomaterials 2011;32:2862-70.
[36] Moss IL, Gordon L, Woodhouse KA, Whyne CM, Yee AJ. A novel thiol-modifiedhyaluronan and elastin-like polypetide composite material for tissue engineering of the nucleus pulposus of the intervertebral disc. Spine (Phila Pa 1976) 2010;36:1022-9.

[37] Chou AI, Akintoye SO, Nicoll SB. Photo-crosslinked alginate hydrogels support enhanced matrix accumulation by nucleus pulposus cells in vivo. Osteoarthritis Cartilage 2009;17:1377-84.

[38] Reza AT, Nicoll SB. Characterization of novel photocrosslinked carboxymethylcellulose hydrogels for encapsulation of nucleus pulposus cells. Acta Biomater 2010;6:179-86.

[39] Nguyen KT, West JL. Photopolymerizable hydrogels for tissue engineering applications. Biomaterials 2002;23:4307-14.

[40] Zhu J. Bioactive modification of poly(ethylene glycol) hydrogels for tissue engineering. Biomaterials 2010;31:4639-56.

[41] Anderson JM, Vines JB, Patterson JL, Chen H, Javed A, Jun HW. Osteogenic differentiation of human mesenchymal stem cells synergistically enhanced by biomimetic peptide amphiphiles combined with conditioned medium. Acta Biomater 2011;7:675-82.

[42] Gonen-Wadmany M, Oss-Ronen L, Seliktar D. Protein-polymer conjugates for forming photopolymerizable biomimetic hydrogels for tissue engineering. Biomaterials 2007;28:3876-86.

[43] Scott R, Marquardt L, Willits RK. Characterization of poly(ethylene glycol) gels with added collagen for neural tissue engineering. J Biomed Mater Res A 2010;93:817-23.

[44] Almany L, Seliktar D. Biosynthetic hydrogel scaffolds made from fibrinogen and polyethylene glycol for 3D cell cultures. Biomaterials 2005;26:2467-77.

[45] Marquardt L, Willits RK. Student award winner in the undergraduate's degree category for the Society for Biomaterials 35th Annual Meeting, Orlando, Florida, April 13-16, 2011. Neurite growth in PEG gels: effect of mechanical stiffness and laminin concentration. J Biomed Mater Res A 2011;98:1-6.

[46] Francisco AT, Mancino RJ, Bowles RD, Brunger JM, Tainter DM, Chen YT, et al. Injectable laminin-functionalized hydrogel for nucleus pulposus regeneration. Biomaterials 2013;34:7381-8.

[47] Peroglio M, Eglin D, Benneker LM, Alini M, Grad S. Thermoreversible hyaluronan-based hydrogel supports in vitro and ex vivo disc-like differentiation of human mesenchymal stem cells. Spine J 2013;13:1627-39.

[48] Gilson A, Dreger M, Urban JP. Differential expression level of cytokeratin 8 in cells of the bovine nucleus pulposus complicates the search for specific intervertebral disc cell markers. Arthritis Res Ther 2010;12:R24.

[49] Lee CR, Sakai D, Nakai T, Toyama K, Mochida J, Alini M, et al. A phenotypic comparison of intervertebral disc and articular cartilage cells in the rat. Eur Spine J 2007;16:2174-85.

[50] Minogue BM, Richardson SM, Zeef LA, Freemont AJ, Hoyland JA. Transcriptional profiling of bovine intervertebral disc cells: implications for identification of normal and degenerate human intervertebral disc cell phenotypes. Arthritis Res Ther 2010;12:R22.

[51] Sakai D, Nakai T, Mochida J, Alini M, Grad S. Differential phenotype of intervertebral disc cells: microarray and immunohistochemical analysis of canine nucleus pulposus and anulus fibrosus. Spine (Phila Pa 1976) 2009;34:1448-56.

[52] Chen J, Yan W, Setton LA. Molecular phenotypes of notochordal cells purified from immature nucleus pulposus. Eur Spine J 2006;15(Suppl 3):S303-11.

[53] Tang X, Jing L, Chen J. Changes in the molecular phenotype of nucleus pulposus cells with intervertebral disc aging. PLoS One 2012;7:e52020.

[54] Gotz W, Kasper M, Fischer G, Herken R. Intermediate filament typing of the human embryonic and fetal notochord. Cell Tissue Res 1995;280:455-62.

[55] Estes BT, Diekman BO, Guilak F. Monolayer cell expansion conditions affect the chondrogenic potential of adipose-derived stem cells. Biotechnol Bioeng 2008;99:986-95.

[56] Chen J, Baer AE, Paik PY, Yan W, Setton LA. Matrix protein gene expression in intervertebral disc cells subjected to altered osmolarity. Biochem Biophys Res Commun 2002;293:932-8.

[57] Kleinman HK, McGarvey ML, Liotta LA, Robey PG, Tryggvason K, Martin GR. Isolation and characterization of type IV procollagen, laminin, and heparan sulfate proteoglycan from the EHS sarcoma. Biochemistry 1982:21:6188-93.

[58] Iatridis JC, Weidenbaum M, Setton LA, Mow VC. Is the nucleus pulposus a solid or a fluid? Mechanical behaviors of the nucleus pulposus of the human intervertebral disc. Spine (Phila Pa 1976) 1996;21:1174-84.

[59] Nettles DL, Chilkoti A, Setton LA. Early metabolite levels predict long-term matrix accumulation for chondrocytes in elastin-like polypeptide biopolymer scaffolds. Tissue Eng Part A 2009;15:2113-21.

[60] Gruber HE, Hanley Jr EN. Human disc cells in monolayer vs 3D culture: cell shape, division and matrix formation. BMC Musculoskelet Disord 2000;1:1-11.

[61] Veronese FM, Pasut G. PEGylation, successful approach to drug delivery. Drug Discov Today 2005;10:1451-8.

[62] Iatridis JC, Setton LA, Weidenbaum M, Mow VC. The viscoelastic behavior of the non-degenerate human lumbar nucleus pulposus in shear. J Biomech 1997; 30:1005-13.

[63] Iatridis JC, Setton LA, Weidenbaum M, Mow VC. Alterations in the mechanical behavior of the human lumbar nucleus pulposus with degeneration and aging. J Orthop Res 1997;15:318-22.

[64] Cruise GM, Scharp DS, Hubbell JA. Characterization of permeability and network structure of interfacially photopolymerized poly(ethylene glycol) diacrylate hydrogels. Biomaterials 1998;19:1287-94. 
[65] Holm S, Maroudas A, Urban JP, Selstam G, Nachemson A. Nutrition of the intervertebral disc: solute transport and metabolism. Connect Tissue Res 1981;8:101-19.

[66] Bibby SR, Jones DA, Ripley RM, Urban JP. Metabolism of the intervertebral disc: effects of low levels of oxygen, glucose, and $\mathrm{pH}$ on rates of energy metabolism of bovine nucleus pulposus cells. Spine (Phila Pa 1976) 2005;30:487-96.
[67] Grunhagen T, Wilde G, Soukane DM, Shirazi-Adl SA, Urban JP. Nutrient supply and intervertebral disc metabolism. J Bone Joint Surg Am 2006;88(Suppl 2):30-5.

[68] Cukierman E, Pankov R, Stevens DR, Yamada KM. Taking cell-matrix adhesions to the third dimension. Science 2001;294:1708-12. 